\title{
Potential land and technology recommendation for cacao in Papua, Indonesia
}

\author{
Afrizal Malik ${ }^{1 *}$, Widia Siska ${ }^{2 *}$, Heppy Suci Wulanningtyas ${ }^{3}$, Merlin K. Rumbarar ${ }^{3}$, Adhe \\ Poppy Wira Etikha ${ }^{2}$, and Irma Susanti ${ }^{1}$ \\ ${ }^{1}$ East Java Assessment Institute for Agricultural Technology, Malang, Indonesia \\ ${ }^{2}$ Indonesian Center for Agricultural Technology Assessment and Development, Bogor, Indonesia \\ ${ }^{3}$ Papua Assessment Institute for Agricultural Technology, Jayapura, Indonesia
}

\begin{abstract}
Cacao is a primary commodity in the Keerom Regency, but production has been decreasing in recent years. Cacao cultivation on unsuitable land and without cutting-edge technology would impede efforts to increase its productivity. The study aimed to evaluate land suitability for cacao in Keerom Regency, Papua, and to suggest site-specific technologies. The study was carried out in the Keerom Regency of Papua in 2015. Land suitability assessment was carried out by matching data on land characteristics (climate, slope, soil type, and soil fertility) with land use requirements for cacao cultivation. The data was analyzed using geographic information systems. The result showed that 78.077 ha $(8.60 \%)$ of the studied area were highly suitable for cacao cultivation, 123.645 ha $(13.63 \%)$ was moderately suitable, and 389.603 ha $(42.94 \%)$ was marginally suitable. About 316.082 ha $(34,83 \%)$ of the studied area was classified as notsuitable. The recommendation technology for increasing cacao yields were fertilization, pruning, shade management, and individual terraces. Cultivation on suitable land and the application of technological innovations are expected to increase cacao production in Keerom Regency, Papua. The findings of this study could be used as a reference for policymakers to establish cacao development in the future.
\end{abstract}

\section{Introduction}

In Keerom Regency of Papua, cacao is one of the most important commodities. However, cacao has not become a commodity capable of moving the community's economy in recent years. Cacao yields are declining due to pests and infections, as well as a lack of attention to cacao cultivation. In addition, the majority of the cacao plants are over 15 years old and have not yet been planted due to land suitability. Research conducted by [1] and [2], have found that declines in cacao productivity are generally caused by land use that is not in accordance with conservation and land suitability rules, the use of less than optimal cacao cultivation technology, poorly maintained cacao plantations, and inferior seeds.

Cacao production improved by cultivating the crop on suitable land and using modern farming techniques. It is critical to have an access to data and information on the suitability

\footnotetext{
*Corresponding author: Malik: malikafrizal62@gmail.com, Siska: widiasiska82@gmail.com
} 
of cacao plantations in Keerom Regency in order to identify limiting factors and make changes. The suitability of land has a large impact on cacao productivity and quality, with altitude, slope, effective depth, phosphorus content, and CEC all having an 82 percent and 91 percent effect on cacao pod productivity and quality, respectively [3]. In 2012, there were 7,528 hectares of cacao planted in Keerom Regency, 7,628 hectares in 2013, 7,754 hectares in 2014, 7,754 hectares in 2015, and 7,791 hectares in 2016 [4]. In the Keerom Regency, cacao plantations are smallholder farms with a low production of $551 \mathrm{~kg} / \mathrm{ha}$ [5]. The yield of cacao in this region is just below the potential yield of numerous better cacao clones that now available, notably those with productivity exceeding 2 tons/ha/year [6]. Cacao planting in smallholder plantations is typically done in the S3 suitability class, efforts must be made to improve it [3].

Cacao productivity and quality are influenced by multiple factors, including land appropriateness and cultivation management. Smallholder plantations maintain the majority of Indonesia's cacao land ( $>90 \%)$ utilizing the simple management. Cacao productivity and quality can be affected by these factors. Superior cacao plant material technology, information on land suitability for cacao, plant propagation technology, major pest and disease control technology, clonalization technology, yield processing technology, and industrial development technology can all be used to improve quality and yield to support increased production and development of cacao [6].

Improvements on limiting variables can be achieved by taking into account the local community's economic and socio-cultural features in order to acquire recommendations for site-specific cultivation techniques for long-term cacao production. The goal of this research was to evaluate land suitable for cacao in Keerom Regency, Papua Province, and to suggest site-specific technologies. This study employs a Geographic Information System. In this region, land suitability assessment and site-specific technological recommendations are critical for cacao production. The findings of this study should have a favorable impact on the development of cacao in Keerom Regency.

\section{Materials and method}

The study was carried out in the Keerom Regency of Papua in 2015. The study area encompasses the entire Keerom Regency, which is located at $140^{\circ} 18^{\prime}-140^{\circ} 55^{\prime} \mathrm{E}$ and $02^{\circ}$ 37'- $3^{\circ} 55^{\prime}$ S. Keerom Regency comprises an area of 907,407 ha, divided into seven districts: Web District, Senggi, Waris, Arso, East Arso, Towe, and Skanto, according to cartographic measurements. Because of its location, the study area is close to Jayapura City on the north side, Papua New Guinea on the east, bordering the Bintang Mountains Regency on the south side, and Jayapura Regency on the west side.

ArcMap 10.1, ERMapper 12, and SAGA GIS were used in this study. Landsat 7 path/row 101/62-63, and 100/63, coverage in 2010 to 2012 and Digital Elevation Model (DEM), $30 \mathrm{~m}$ resolution, available from the USGS Earth Explorer Portal (http://eartheexplorer.usgs.gov/) were utilized in this work. Other data utilized were a digitized Indonesia topographical map at 1:50,000 scale from the Indonesia Geospatial Information Agency, and Geological Maps Keroom (3412) and Jayapura (3413) sheets at 1:250,000 scale from Litbang Geologi (1995).

Data on climate, topography, and soil were examined as land suitability characteristics. Climatic parameters collected included rainfall data from the Arso meteorological station during a 10-year period, as well as air temperature, humidity, and sunshine duration from the Sentani meteorological station. Analysis of DEMs data with a resolution of $30 \mathrm{~m}$ yielded topographic characteristics such as relief and slope class. A stratified random sampling approach was employed to collect soil data. The soil was evaluated using the methods described in Soil Survey Investigation Report No. 1 [7] and the Soil Analysis Guide [8]. 
The Land Suitability Assessment System (SPKL) was used by the Indonesian Center for Agricultural Land Resources Research and Development. The FAO framework was used for land suitability assessment, and the Land Use Requirements (Land Utilization Types, LUT) system was used to compare land quality/land characteristics to land use requirements. Land suitability was separated into highly suitable (S1), moderately suitable (S2), marginally suitable (n), and not suitable (N) [9]. The most dominant/severe limiting factor was used to separate land suitability classes into land suitability sub-classes. The Technical Guidelines for Land Evaluation for Agricultural Commodities were used to determine land suitability [10], while technology for cacao cultivation was obtained from a literature review.

\section{Results and discussion}

The climate balance describes the balance between the amount of precipitation and evapotranspiration, and is expressed in surplus and deficit. The calculation of the water balance for the study area was based on the Penman-Tronthwaite method [11]. Calculations were based on a clayey texture with a water holding capacity of $300 \mathrm{~mm} / \mathrm{m}$. Based on the results of the calculation of the precipitation balance, it shows that Keerom Regency does not have a deficit or water scarcity for cacao cultivation throughout the year. Figure 1 is the climate balance in the Keerom Regency, Papua.

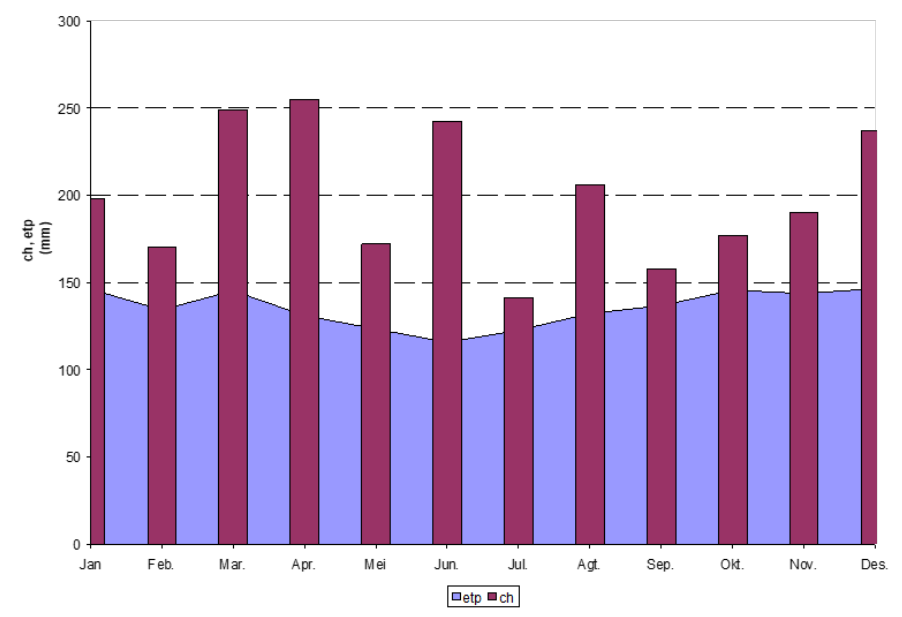

Fig. 1. Climate balance in the Keerom Regency, Papua

The result of analysis showed that landforms in Keerom Regency were classified into 5 groups, namely: Alluvial, Peat, Karst, Volcanic, and Tectonic. Tectonic groups dominate Keerom Regency, covering about 502,320 ha, or $55.36 \%$ of the total area. Furthermore, the alluvial group covers 220,373 ha $(24.29 \%)$ and it is spread throughout almost all the flat areas in the Skanto, Arso, Waris, and Senggi districts, which are the center of crop farming and plantations. Karst covers about 99.516 ha (10.97\%), Volcan covers about 75,639 ha $(8.36 \%)$, and Peat covers about 9,359 ha (1.03\%) in Senggi District. The distribution of landforms in Keerom Regency is presented in Figure 2. 


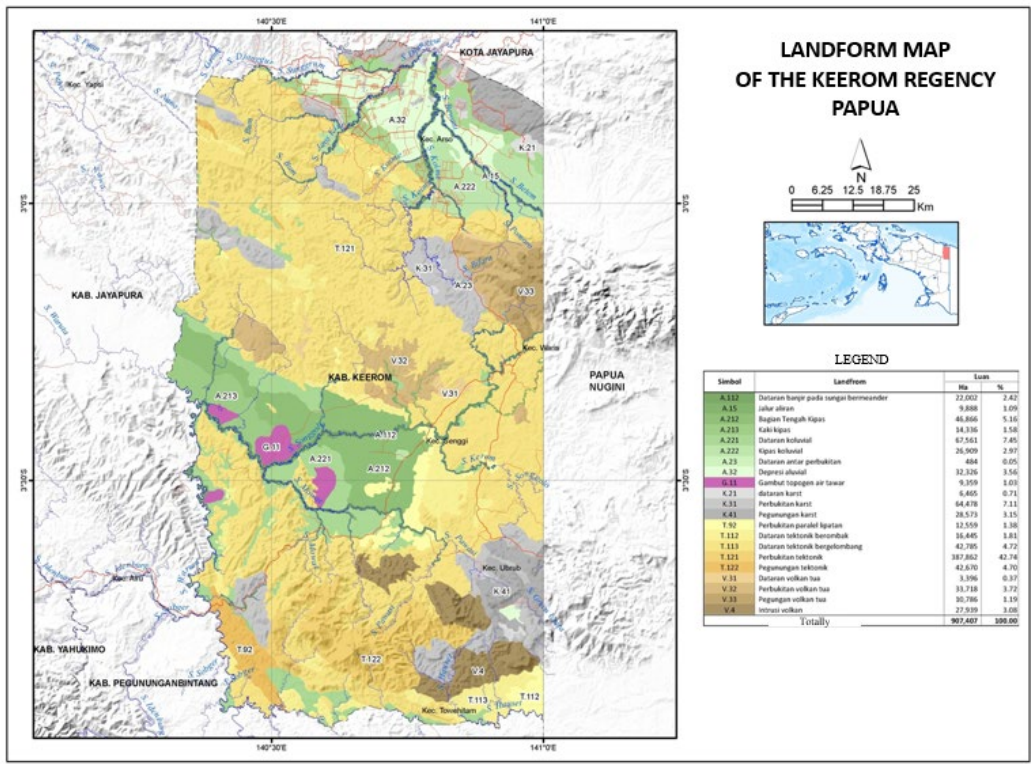

Fig. 2. Landform map of the Keerom Regency, Papua

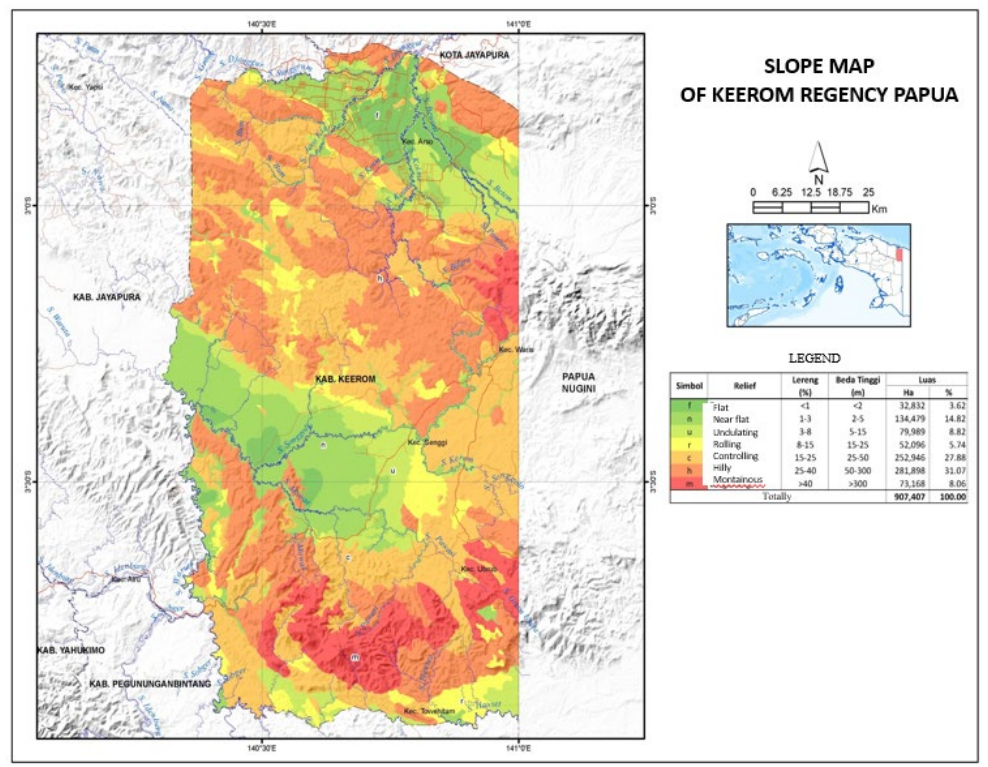

Fig. 3. Slope map of the Keerom Regency, Papua

Figure 3 shows the Keerom Regency slopes in detail. The slopes in Keerom Regency were divided into seven classes: flat was about 32,832 ha $(3.62 \%)$, near flat was about 134,479 ha $(14.82 \%)$, undulating was about 79,989 ha $(8.82 \%)$, rolling was about 52,096 ha (5.74\%), controlling was about 252,946 ha $(27.88 \%)$, hilly was about 281,898 ha $(31.07 \%)$, and mountainous was about 73,168 ha $(8.06 \%)$. Based on observations and supported by chemical analysis from the laboratory, soils in Keerom Regency were classified into 7 orders, namely: Histosols, Entisols, Inceptisols, Andisols, Alfisols, Ultisols, and Oxisols. 


\subsection{The land potential for cacao}

The results of the land suitability evaluation suggested that 591,325 ha (65.17 percent) of the land in Keerom Regency could be developed for agricultural development, while the remaining 316,082 ha (34.83 percent) could not be developed for agriculture due to the biophysical conditions of the land. It was quite likely that land degradation and environmental damage would occur if these regions are pushed to be developed for agriculture. As a result, the site has been designated as a conservation reserve.

Furthermore, cacao development could be carried out on dry land, covering 591,325 ha (65.17 percent), with highly suitable (S1) covering 78,077 ha (8.60 percent), moderately suitable (S2) covering 123,645 ha (13.63 percent), and marginally suitable (S3) covering 591,325 ha (65.17 percent). S2 land contained land restrictions such as erosion hazard (eh), oxygen availability (oa), root capability (rc), and nutrient retention (nr). S3 land contained land constraints such as erosion hazard (eh), nutrient retention (nr), and oxygen availability (oa). Suitable land occupies flat to hilly slopes (slope $<40 \%$ ). Meanwhile, cacao production was unsuitable on 316,082 hectares (34.83 percent) of land. In those area, very steep slopes ( $>40 \%)$, regularly flooded land, and a shallow soil cover $(50 \mathrm{~cm})$ was all significant constraints. The findings of the land suitability for cacao development in Keerom Regency are shown in Table 1, and the distribution of land suitability for cacao is shown in Figure 4.

Table 1. Classification of Cacao Land Suitability

\begin{tabular}{|c|c|r|r|}
\hline Land suitability & Limiting factors & Hectares & $\%$ \\
\hline S1 & - & 78.077 & 8,60 \\
\hline S2eh & Erosion hazard & 27.373 & 3,02 \\
\hline S2oa & Oxygen availability & 90.356 & 9,96 \\
\hline S2rc & Roots capability & 5.343 & 0,59 \\
\hline S2nr & Nutrient retention & 573 & 0,06 \\
\hline S3eh & Erosion hazard & 266.347 & 29,35 \\
\hline S3oa & Oxygen availability & 57.707 & 6,36 \\
\hline S3nr & Nutrient retention & 65.549 & 7,22 \\
\hline & Subtotal & 591.325 & 65,17 \\
\hline Neh & Erosion hazard & 265.273 & 29,23 \\
\hline Noa & Oxygen availability & 9.359 & 1,03 \\
\hline Nrc & Roots capability & 41.449 & 4,57 \\
\hline & Subtotal & 316.082 & 34,83 \\
\hline & Totally & 907.407 & 100,00 \\
\hline
\end{tabular}




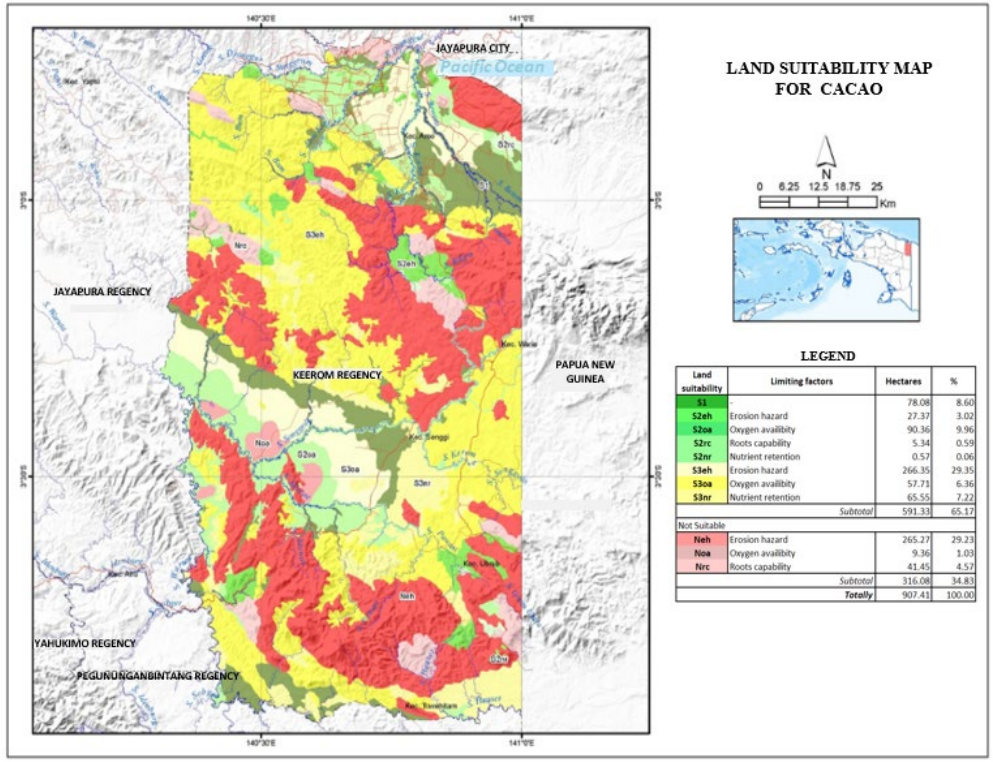

Fig. 4. Cacao land suitability map

The appropriateness of the land is an important aspect in increasing a plant's productivity [12]. As a result, growing cacao on appropriate terrain in Keerom Regency is likely to boost cacao production. Cacao production may also be boosted by expanding the planting area and implementing technological advancements.

\subsection{The technology recommendation for cacao}

Improving land productivity should primarily focus on increasing farmers' income while expanding the farming system in Keerom Regency. One things that may be done is to use technology that farmers can perform technically and commercially lucrative. Increased land productivity may be accomplished by designing an adequate cropping pattern, a planting schedule that incorporates the risk of crop failure, and supplying balanced fertilizer requirements, according to the findings of the land resource studies.

Cacao is often grown in yards or fields with an average plant age of more than three years, following the pattern of community plantations. The majority of small farmers do not utilize fertilizers in cacao farming, resulting in low yields, despite the fact that the use of fertilizers is one strategy to increase cacao production [13]. According to George [14], this is related to farmers' perceptions of risk and low return on investment. Fertilizer treatment on cacao trees can enhance yields by roughly $34 \%$ [15]. In addition, Nelson et al [16], stated that cacao needs $29.7 \mathrm{~kg}$ of nitrogen $(\mathrm{N}), 5.8 \mathrm{~kg}$ of phosphorous $(\mathrm{P})$, and $47.8 \mathrm{~kg}$ of potassium $(\mathrm{K})$ to produce a ton of cacao pods. Fertilization should be done twice a year, at the beginning and ending of the rainy season, respectively. Fertilization at the beginning of the rainy season, depends on the quantity of rain that falls over the course of three rainy decades ( 3 fundamentals) with rainfall of $150 \mathrm{~mm}$.

Pruning and shade management are two aspects of plant care that are equally significant in cacao farming. Pruning is one of the efforts made to ensure that the rate of photosynthesis runs as efficiently as possible in order to produce the most fruit and limit the danger of disease. Angela and Efendi [17], identified that pruning can improve cacao trees' resistance to pests and diseases and have an impact on the number of flower cushions, as well as provide a conducive environment for cacao growth [18]. Pruning is done on non-productive branches and should be done once a month. Shape pruning, maintenance pruning, and production 
pruning are the three types of pruning that are advised for intensification cultivation. Cacao is a shade-loving plant that does well in the shade, and can not grow well in full light [19]. However, heavy shade also has a negative impact on cacao growth [20]. This plant's shadow needs vary widely depending on its stage of development, with early stages requiring up to $75 \%$ shade. This amount is subsequently lowered to around $25 \%$ when cacao is made [21]. According to Abdulai [22], the minimal shade increased cacao yields in rainy areas. Plant adjust their morphology and physiology to adapt to varying light circumstances in order to efficiently utilize sunlight [23]. Shade management has a favorable impact on cacao yields because it may produce an environment that improves the cacao plant's physiology and minimizes insect and disease [24], increases soil carbon by $6 \%$ and total nitrogen by $24 \%$ [25] and also enhanced soil moisture [26].

Individual terraces are recommended for conservation efforts in sloping cacao fields. Individual terraces are those that are dedicated to a single tree (perennial plants only). This terrace helps to decrease erosion while also increasing groundwater supply for annual crops. According to Amfo et al [27], preserving groundwater in cacao production might boost productivity. Individual terrace rows do not have to run in the same direction as the contour line, but rather in the direction that is best for growing crops. The length between each terrace corresponds to the recommended planting distance, and in the intervals between terraces, ground cover legumes should be planted.

\section{Conclusion}

Keerom regency has great potential land for cacao development, with a suitable land area of 591.325 hectares, or 65.17 percent of the total area. Land suitability for cacao consists of S1 (8.60 percent), S2 (13.63 percent), and S3 (65.17 percent). The obstacles to cacao development in Keerom Regency are erosion hazard (eh), oxygen availability (oa), root capability (rc), and nutrient retention (nr). The cultivation technology for increasing cacao yields such as fertilization, pruning, shade management, and individual terraces. Cultivation on suitable land and the application of technological innovations are expected to increase cacao production in Keerom Regency, Papua. The findings of this study could be used as a reference for policymakers in the Keerom regency to establish cacao development in the future.

\section{References}

1. M. Liyanda, A. Karim, and Y. Abubakar, Analisis kriteria kesesuaian lahan terhadap produksi kakao pada tiga klaster pengembangan di Kabupaten Pidie, Agrista, 16, 2, $62-$ 79, (2012)

2. D. S. Jayanti, S. Goenadi, and P. Hadi, Evaluasi kesesuaian lahan dan optimasi penggunaan lahan untuk pengembangan tanaman kakao (Theobroma cacao L.) (Studi Kasus di Kecamatan Batee dan Kecamatan Padang Tiji Kabupaten Pidie Propinsi Aceh), Agritech, 33, 02, 208-218, (2013)

3. T. Nofelman, A. Karim, and A. Anhar, Analisis Kesesuain Lahan di Kabupaten Simeulue, Manaj. Sumberd. Lahan, 1, 1, 62-71, (2012)

4. [Badan Pusat Statistik] BPS, Kabupaten Keerom Dalam Angka 2019. Badan Pusat Statistik Kabupaten Keerom, (2019)

5. Directorate General of Estate Crops, Tree Crop Estate Statistics Of Indonesia 2013-2015, Cocoa. Directorate General of Estate Crops, Jakarta, (2014)

6. Rubiyo and Siswanto, Peningkatan Produksi dan Pengembangan Kakao ( Theobroma cacao L. ) di Indonesia, J. Ind. Beverage Crop, 3, 1, 33-48, (2012) 
7. Soil Survey Staff, Procedures for collecting soil samples and methods of analysis for soil survey. Soil Survey Investigations, Report 1, U.S. Gov. Print. Office, Washington, D.C, (1972)

8. Sulaeman, Suparto, and Eviati, Petunjuk Teknis Analisis Kimia Tanah, Tanaman, Air, dan Pupuk. Balai Penelitian Tanah, Bogor. 136 Halaman. (2005)

9. [Food and Agriculture Organization] FAO, A framework for land evaluation. Food and Agriculture Organization of the United Nations, Soils Bulletin 32. Rome. Italy, (1976)

10. S. Ritung, K. Nugroho, A. Mulyani, and E. Suryani, Petunjuk Teknis Evaluasi Lahan untuk Komoditas Pertanian (Edisi Revisi). Balai Besar Penelitian dan Pengembangan Sumberdaya Lahan Pertanian Badan Penelitian dan Pengembangan Pertanian Bogor, (2011)

11. C. W. Thornthwaite and J. R. Mather, Instruction and Tables for Computing Potential Evapotranspiration and for Computing Potential Evapotranspiration and Water Balance. Drexel Institute of Technologi Laboratory of Climatology, New Jersey: Centerton. X, 3, (1957)

12. H. A. Adornado and M. Yoshida, Crop Suitability and Soil Fertility Mapping using Geographic Information System (GIS), Agric. Inf. Res, 17 (2), 60-68, (2008)

13. A. Afrifa, K. O.- Frimpong, S. Acquaye, D. Snoeck, and M. K. Abekoe, Soil nutrient management strategy required for sustainable and competitive cocoa production in Ghana Some Key Information on nutrient and their availability required for cocoa, 16th Int. Cocoa Conf, January, 16-21, (2009)

14. T. George, Why crop yields in developing countries have not kept pace with advances in agronomy, Glob. Food Sec, 3, 1, 49-58, (2014)

15. M. P. Hoffmann, J. Cock, M. Samsonc, N. Janetskid, K. Janetskid, R. P. Rötterb, M. Fisherf, T. Oberthürc, Fertilizer management in smallholder cocoa farms of Indonesia under variable climate and market prices, Agric. Syst, 178, (2020)

16. P. N. Nelson, M. J. Webb, S. Berthelsen, G. Curry, D. Yinil, and C. Fidelis, Nutritional status of cocoa in Papua New Guinea. ACIAR Commonwealth of Australia. (2011)

17. Angela and D. Efendi, Pengelolaan Pemangkasan Tanaman Kakao (Theobroma Cacao L.) Di Cilacap, Jawa Tengah, Bul. Agrohorti, 3, 3, 285-293, doi: 10.29244/agrob.v3i3.15800, (2015)

18. W. Niether, L. Armengot, C. Andres, M. Schneider, and G. Gerold, Shade trees and tree pruning alter throughfall and microclimate in cocoa (Theobroma cacao L.) production systems, Ann. For. Sci. 75, 2, 1-16, (2018)

19. A. M. Lennon, V. R. Lewis, A. D. Farrell, and P. Umaharan, Photochemical responses to light in sun and shade leaves of Theobroma cacao L. (West African Amelonado), Sci. Hortic. (Amsterdam). 276, 109747, (2021)

20. E. Arévalo-Gardini, A. Farfán, F. Arraza, C. O. Arévalo-Hernández, J. Zúñiga-Cernades, Luis B Alegre, and V. C. Baligar, Growth, Physiological, Nutrient-Uptake-Efficiency and Shade-Tolerance Responses of Cacao Genotypes under Different Shades, Agronomy, 11, 8, 536, (2021)

21. K. P. P. Nair, Cocoa (Theobroma cacao L.), (2010)

22. I. Abdulai, L. Jassogne, S. Graefe, R. Asare, P.V. Asten, P. Laderach, and P. Vaast, Characterization of cocoa production, income diversification and shade tree management along a climate gradient in Ghana. PLoS One. 13, 4, p. e0195777, (2018)

23. F. Valladares and Ü. Niinemets, Shade tolerance, a key plant feature of complex nature and consequences, Annu. Rev. Ecol. Evol. Syst. 39, 237-257, doi: 10.1146/annurev.ecolsys.39.110707.173506, (2008)

24. W. Vanhove, N. Vanhoudt, and P. Van Damme, Effect of shade tree planting and soil management on rehabilitation success of a 22-year-old degraded cocoa (Theobroma 
cacao L.) plantation, Agric. Ecosyst. Environ, 219, 14-25, doi: 10.1016/j.agee.2015.12.005, (2016)

25. A. C. Wartenberg, W. J. Blaser, J. M. Roshetko, M. Van Noordwijk, and J. Six, Soil fertility and Theobroma cacao growth and productivity under commonly intercropped shade-tree species in Sulawesi, Indonesia, Plant Soil, 453, 1-2, 87-104, doi: 10.1007/s11104-018-03921-x, (2020)

26. W. Niether, U. Schneidewind, L. Armengot, N. Adamtey, M. Schneider, and G. Gerold, Spatial-temporal soil moisture dynamics under different cocoa production systems, Catena, 158, 340-349, doi: 10.1016/j.catena.2017.07.011, (2017)

27. B. Amfo, E. B. Ali, and D. Atinga, Climate change, soil water conservation, and productivity: Evidence from cocoa farmers in Ghana, Agric. Syst, 191, 103172, doi: 10.1016/j.agsy.2021.103172, (2021) 